\title{
Entre a loucura e a lucidez: crônicas de Clarice Lispector no Jornal do Brasil
}

\author{
YUDITH ROSENBAUM \\ Universidade de São Paulo
}

\begin{abstract}
This article approaches the territory of madness and unreason in Lispector's fiction, an aspect of her work that is present in her press contributions "Das doçuras de Deus" (16 Dec. 1967), "Sem nosso sentido humano" (28 Jun. 1969), "Loucura diferente" (8 Dec. 1970), and "Lucidez perigosa" (2 May 1972). None of these texts became an autonomous short story or novel, as happened with many others originally published in Jornal do Brasil between 1967 and 1973. This study examines these four texts with a view to grasping a Claricean poetics, as it is represented through extreme perceptions of madness and unreason. I consider these texts as pre-figurations or instances of contact with motives such as freedom, adaptation, fear and habit. The texts examined here are shown to defy hegemonic rationality while pointing to the limits of discursive language.
\end{abstract}

Keywords: Chronicles, journalism, madness, unreason, poetics

O campo da loucura e da desrazão na obra de Clarice Lispector é bastante mencionado e pouco desenvolvido pela fortuna crítica da autora. Especialmente suas crônicas, publicadas no Jornal do Brasil entre 1967 e 1973, guardam reflexões importantes sobre o tema e que podem ser reconhecidas, ainda que dispersamente, em seus contos e romances.

A partir dessa premissa, pretende-se explorar alguns textos cronísticosmuitos deles fragmentos confessionais, outros de feição mais ficcional-que trariam marcas e traços de uma visão problematizadora do conflito entre razão e 
desrazão, normalidade e loucura. Seguindo tais escritos, que se abrem à uma poética clariciana sobre o ato criador, talvez se possa compreender melhor os processos de construção e desconstrução do sujeito moderno, tópico fundante da obra clariciana.

\section{Lucidez e risco}

É sabido que Lispector faz da sua escrita um percurso constante de experimentação das extremidades, dos estados radicais de percepção, o que já foi compreendido como "epifania," estado de graça ou instantes de revelação e descortínio da realidade. Essa compreensão está presente em estudos de Benedito Nunes, Olga de Sá, Afonso Romano Sant'anna ("Clarice: a epifania da escrita") e mais recentemente João Camillo Pena, entre outros. Tanto quanto suas personagens, é a própria matéria viva textual que se desloca de espaços conhecidos e familiares para adentrar o território do estranhamento. Ou seja, seus agentes se surpreendem ao ultrapassar cercas do conhecimento de si mesmos, rompendo acomodações já instauradas nas quais o viver é o hábito. Assim, também a linguagem se desestabiliza por novas proposições semânticas e sintáticas. Afirma Gilles Deleuze sobre o problema do escrever: "o escritor como diz Proust, inventa na língua uma nova língua, uma língua de algum modo estrangeira. Arrasta a língua para fora de seus sulcos costumeiros, leva-a a delirar" (9).

No limite, ambas - escrita e personagem — tangenciam significações desarrazoadas e enlouquecidas. O caminho entrelaça forma e conteúdo e as ressonâncias entre palavra e mundo (do eu e do outro) atingem níveis estéticos imprevistos. É o que se propõe no primeiro parágrafo do conto "Os obedientes," uma boa porta de entrada para, em seguida, percorrermos as crônicas: "Trata-se de uma situação simples, um fato a contar e esquecer. Mas se alguém comete a imprudência de parar um instante a mais do que deveria, um pé afunda dentro e fica-se comprometido ... " (A legião estrangeira 99). O aviso é claro: o ato de parar, quando se deveria "contar e esquecer," representa "afundar dentro" (sem que se saiba bem no quê...) e se comprometer. Entendo que a literatura de Lispector nos convida a essa parada, jogando-nos no risco de um compromisso, ao tocarmos em algo por um instante a mais do que deveríamos. Situações 
simples se alojam sob águas turbulentas e é para elas que os textos claricianos nos arrastam.

A mesma ideia ressurge na crônica "Lucidez perigosa" (publicada no Jornal do Brasil em 5 de fevereiro de 1972), prenúncio do que poderia se aproximar do que trataremos aqui como desrazão. O texto é uma espécie de matriz temática do embate entre as artimanhas dos processos adaptativos e uma estranha "lucidez vazia," na qual o sujeito perde seus limites e contornos:

Estou sentindo uma clareza tão grande que me anula como pessoa atual e comum: é uma lucidez vazia, como explicar? Assim como um cálculo matemático perfeito do qual, no entanto, não se precise. Estou por assim dizer vendo claramente o vazio. E nem entendo aquilo que entendo pois estou infinitamente maior do que eu mesma, e não me alcanço. Além do quê: que faço dessa lucidez? Sei também que essa lucidez pode se tornar o inferno humano-já me aconteceu antes. Pois sei que-em termos de nossa diária e permanente acomodação resignada à realidadeessa clareza de realidade é um risco. Apagai, pois, minha flama, Deus, porque ela não me serve para viver os dias. Ajudai-me a de novo consistir nos modos possíveis. Eu consisto, eu consisto, amém. (A descoberta do mundo 403)

Embora condensado, esse pequeno texto parece abarcar várias preocupações constantes da autora e que serão revisitadas em toda obra. Clareza, vazio, excesso, lucidez, não compreensão, infinitude, anulação da pessoa, perigo da flama, todas essas expressões remetem a um estatuto diferenciado e contrastante com a nossa "diária e permanente acomodação resignada à realidade." O sujeito dividido entre ser e pertencer, que precisa proteger-se da clareza da realidade (pois ela "é um risco"), domina as narrativas de Lispector desde seu primeiro livro, Perto do coração selvagem. Nele, a protagonista Joana transita por estados pouco convencionais e transgride os contornos mais definidos: "Perco a consciência, mas não importa, encontro a maior serenidade na alucinação" (15), diz ela. Ou ainda: "O estado para onde deslizava quando murmurava: eternidade. Aprofundava-se magicamente e alargava-se, sem propriamente um conteúdo e uma forma, mas sem dimensões também" (37). Para Joana, "a coisa não 
precisava ser triste ou alegre ou se manifestar. Bastava existir, de preferência parada e silenciosa, para nela se sentir a marca. Por Deus, a marca da existência ... " (40). A "marca da existência," do que seria a própria tessitura do viver, é um êxtase e um abismo. Basta existir "parada e silenciosa." Na crônica, o perigo se anuncia com a frase: "Além do quê: que faço dessa lucidez? Sei também que essa lucidez pode se tornar um inferno humano," ou seja, afunda-se dentro quanto mais se adquire lucidez da realidade. Desse mergulho pode advir tanto a mais intensa revelação quanto uma dolorosa perdição. O narrador, que desde o início se observa em sua vivência atual através do gerúndio- "Estou sentindo" e também "Estou por assim dizer vendo claramente o vazio" (grifos meus) afirma, ainda, a sensação de uma anulação de si, algo como uma desindividuação, que o leva a não se entender e a se perder no infinito. E atesta que já experimentou tal estado ("Já me aconteceu antes"), o que legitima o processo pelo ato testemunhal e acenapara uma repetição.

Essa "lucidez embriagada" instaura uma aporia entre a consciência extática do vazio, verdadeira "iluminação profana" próxima ao visionarismo, e a impossível finalidade de tal percepção, posto que anula o indivíduo comum. ${ }^{1} \mathrm{O}$ narrador roga para que Deus apague sua flama (desde a mitologia, o excesso de visão é cegante...) e o faça “consistir nos modos possíveis.” De fato, a vivência do ilimitado, em que o ego diário cede lugar a uma experiência incompreensível do próprio infinito de si, "não serve para viver os dias," diz a cronista.

À propósito, relembro ao leitor o conto "Amor," no qual a personagem Ana, dona-de-casa adaptada à sua rotina doméstica, é subitamente arrancada de seu prosaico cotidiano, a partir da visão de um cego mascando chicle no ponto de um bonde. Em meio ao transe epifânico no Jardim Botânico ("Tudo era estranho, suave demais, grande demais"), o narrador comenta: "O que o cego desencadeara caberia nos seus dias?" (Laços de família 40). A frase ressoa a mesma da crônica: "não serve para viver os dias." Ao final do conto, Ana se vê reabrigada em seu lar e novamente surge o significante "flama:" "Antes de se deitar, como se apagasse uma vela, soprou a pequena flama do dia" (Laços de família 41). Tratase de uma vivência desterritoralizante similar a que é descrita na crônica "Lucidez perigosa." José Miguel Wisnik afirma que essa "experiência de

\footnotetext{
${ }^{1}$ Para o conceito de "lucidez embriagada," ver Pellegrino.
} 
descarrilamento existencial, da parte das mulheres, é recorrente no livro [Laços de família], colocando-as no limiar da dificil volta à norma" ("Diagramas" 289). Para Wisnik, o retorno de Ana, "depois de tudo, implica ficar suspensa por um fio entre o dentro e o fora da cena familiar " ("Diagramas" 289).

Voltando à crônica, reconhecemos a busca clariciana de uma expansão da consciência, às vezes paradoxalmente pela imersão no inconsciente e outras pela absorção na (e da) presença do objeto, ao mesmo tempo em que se vive a iminência do naufrágio. $\mathrm{O}$ apelo a Deus como forma de conter o excesso da flama encerra a crônica em tom de oração e prece: "Eu consisto, eu consisto, amém." A expressão mencionada acima, "Iluminações profanas," foi retirada do ensaio de Wisnik, "Iluminações profanas (poetas, profetas, drogados)," que por sua vez se inspirou em reflexão de Walter Benjamin sobre o surrealismo. A certa altura, Wisnik diz:

O olhar visionário é pois uma experiência que resulta do apagamento da visão habitual (o excesso que acompanha a falta da visão comum) e que fala por enigmas [...]. A visão excede o foco e os limites do ego (se se pode dizer assim), e o sujeito se vê tomado, possuído e intensivamente superado pela própria força da visão. (284)

Esse trecho toca de perto a crônica de Lispector, que presentifica o olhar excessivo e a desnorteante perda do hábito ou da "visão habitual."

\section{Perigosa desrazão}

Apropriei-me linhas atrás do termo "desrazão" para nomear, de forma aproximada e analógica, a extasiante e infernal iluminação presente na crônica "Lucidez perigosa." É preciso esclarecer tal noção, que possui uma longa tradição filosófica e literária. Segundo Peter Pál Pelbart, apoiado em Michel Foucault, a relação do homem com a sua Alteridade conheceu diversas formas ao longo da história. Na Grécia antiga, o modo de se conectar com esse Exterior a nós (que não pertencia a ninguém em particular) se dava pelo trânsito dinâmico da Mania, da Insensatez e do Desatino. Regido por rituais e cerimônias sagradas, o indivíduo mobilizava o acesso a esse território da desrazão - também definido 
como "o Fora," por Maurice Blanchot, e depois como "O pensamento do Fora," por Foucault. Importa aqui pensar esse "Fora," de onde se alimenta a desrazão, como um jogo de forças que não está confinado a uma personagem social reclusa, tal como o louco a partir da Idade Clássica. Esse grande Exterior ao Homem (de acesso aberto ao coletivo) surgia como absolutamente estranho, manifestando-se em figurações diversas: Aventura da Linguagem, Caos do Mundo, Estranheza da Natureza etc. Embora vizinha da loucura, a desrazão dela se diferencia como um campo de intensidades pelo qual se pode transitar sem nele aprisionar-se.

Blanchot pensou a experiência do "Fora" (Les Dehors), fonte da desrazão, como o próprio cerne da literatura. Deixando de ser uma forma de conhecimento mimético do mundo, o espaço literário seria o habitat do Fora. A palavra literária, ao fundar sua própria realidade, nega o real para erigir a irrealidade da ficção e ao fazê-lo presentifica a ausência do mundo sensível. A obra seria a presença do desaparecimento das coisas que se tornam linguagem. Nas palavras de Blanchot: "Quando eu falo, reconheço que só existe palavra porque o "é" desapareceu no que o nomeia, fulminado para se tornar a realidade do nome: a vida desta morte, eis o que é admiravelmente a palavra" (50).

Para tornar a ideia ainda mais clara, vejamos como Tatiana Salem Levy explica o pensamento de Blanchot, que conecta o Fora à literatura:

É certo, pois, que a literatura fala de realidade, mas não de uma realidade familiar, dada pelo mundo cotidiano. O realismo da ficção joga o leitor num mundo de estranhamento, onde não é mais possível se reconhecer. A ficção aparece como o inabitual, o insólito, o que não tem relação com esse mundo nem com esse tempo - o outro de todos os mundos, que é sempre distinto do mundo. Mas ao mesmo tempo em que nos retira do mundo, nele nos coloca novamente. E nós o vemos então com outro olhar, pois a realidade criada na obra abre no mundo um horizonte mais vasto, ampliado [...]. O Fora é exatamente esse outro de todos os mundos que é revelado pela literatura." (25-26)

Portanto, o contato com o Fora, segundo Blanchot, é vital para a literatura, mas pode ser uma deriva arriscada, tanto no contexto literário quando fora dele. $\mathrm{Na}$ crônica seguinte, "Ir contra uma maré," de 1970, a autora comenta esse flerte 
perigoso com a desrazão, mas sob domínio de um logos que é tanto a razão controladora quanto a própria linguagem ordenadora:

Lutei toda a minha vida contra a tendência ao devaneio, sempre sem jamais deixar que ele me levasse até as últimas águas. Mas o esforço de nadar contra a doce corrente tira parte de minha força vital. E, se lutando contra o devaneio ganho no domínio da ação, perco inteiramente uma coisa muito suave de se ser e que nada substitui. Mas um dia ainda hei de ir, sem me importar para onde o ir me levará. (A descoberta do mundo 284)

Aqui o conflito clássico pensado pela psicanálise entre princípio de realidade (“domínio da ação") e princípio do prazer (“doce corrente" do devaneio) se coloca para a cronista desde sempre ("a minha vida toda"). A cultura se constrói justamente nessa renúncia, nesse "nadar contra" as pulsões que demandam descarga e satisfação. Para Sigmund Freud, o psiquismo humano e a sociedade se fundam nessa dinâmica que opõe desejo e vida social ("O mal estar na civilização").

Curioso notar que a crônica termina com a afirmação do anseio de se entregar ao devaneio - "Mas um dia ainda hei de ir, sem me importar para onde o ir me levará"-, enquanto no texto anterior dá-se o contrário, pois o narrador pede a Deus que apague a flama: "Ajudai-me de novo a consistir nos modos possíveis." Por um lado, na primeira crônica comentada, Lispector cronista precisa de ajuda para sair do transe, da perigosa lucidez do vazio; por outro, no texto seguinte, começa lutando para resistir ao apelo da miragem das águas da doce corrente, mas termina na promessa de não resistir mais. Duas atitudes que se complementam, como dois lados da mesma moeda. Razão e desrazão atuam juntas em movimentos de oposição. O esforço de resistir ao doce enleio do devaneio implica no desgaste da "força vital" da cronista e, sobretudo, da perda "de uma coisa muito suave de ser e que nada substitui." "Ir" sem freios, sem se importar para onde, é o desejo interceptado pela vida construída e administrada. Nesse sentido, vale citar, ainda que longo, um trecho do ensaio já mencionado de Freud sobre os dois princípios que regulam a economia psíquica e social, em que o lugar da arte ocupa um terreno intermediário, ponte entre ambos os polos, de modo a salvaguardar tanto as possibilidades de prazer, quanto as demandas da 
realidade. O sujeito moderno e o mal estar que resulta desse confronto são apresentados com clareza:

A arte ocasiona uma reconciliação entre os dois princípios, de maneira peculiar. Um artista é originalmente um homem que se afasta da realidade, porque não pode concordar com a renúncia à satisfação instintual que ela a princípio exige, e que concede a seus desejos eróticos e ambiciosos completa liberdade na vida de fantasia. Todavia, encontra o caminho de volta deste mundo de fantasia para a realidade . . Mas ele só pode seguir isto porque outros homens sentem a mesma insatisfação que ele com a renúncia exigida pela realidade, e porque essa insatisfação, que resulta da substituição do princípio de prazer pelo princípio de realidade, é em si uma parte da realidade. (Freud, "Formulações" 284)

Essa passagem freudiana nos abre caminho para uma outra crônica de Lispector que aborda justamente essa diferença entre a loucura do artista e a loucura do doente. Se o escritor para Freud, como vimos acima, reencontra o caminho de volta ao dar forma às suas fantasias, que se afinam com as mesmas insatisfações do leitor, podemos situar a escrita artística como um lugar possível para a desrazão no mundo moderno. De fato, para Pelbart, as "máscaras da desrazão contemporânea" encontram-se hoje nas formas literárias abertas por Franz Kafka, Stéphane Mallarmé, Antonin Artaud e Friedrich Hölderlin ao lado de filósofos como Friedrich Nietzsche, Blanchot, Deleuze, entre outros. Pela arte e por certa linhagem filosófica, portanto, a modernidade manteria sua relação com o Fora, do qual a loucura foi alijada e marginalizada (Pelbart).

Dentro desse panorama, a crônica "Loucura diferente," de 1970, pode ser lida tendo como chave a cisão ocorrida a partir da Idade Clássica, entre loucura/desrazão e loucura/doença mental. De Platão a Hegel, como mostra Foucault, a experiência trágica da loucura — na qual o saber que ela porta é exterior à razão, mas que mantém com ela uma comunicação aberta-essa singular vivência do Inquietante será, na Renascença, eclipsada pela descoberta de uma loucura imanente à razão que abocanha o Estranheza sem nome, para o que conhecemos hoje como loucura/doença mental, esvaziada de seu poder sagrado e infamiliar da Grécia arcaica. Como diz Foucault, a partir da experiência 
clássica da loucura, a chamada "nau dos insensatos," que levava os loucos para a errância do mar sem fim, será substituída pela internação: “[o] esquecimento cai sobre o mundo sulcado pela livre escravidão de sua Nau: ela não irá mais de um aquém para um além, em sua estranha passagem; nunca mais ela será esse limite fugidio e absoluto. Ei-la amarrada, solidamente no meio das coisas, e das pessoas. Retida e segura. Não existe mais a barca, porém o hospital" (43). Ainda segundo o filósofo, a loucura na Idade Clássica não diz tanto respeito à verdade e ao mundo "quanto ao homem e à verdade de si mesmo que ele acredita distinguir" (25). A mesma ideia reaparece nas palavras de Pelbart: "enquanto a desrazão é a experiência percebida como inumana, atemporal e onipresente, que enuncia, no silêncio ou na desforra, uma verdade do mundo, a loucura remete à experiência temporal de um tipo social excluído, e que exprime, no excesso de suas paixões, a verdade do homem" (57).

Vejamos, então, o que seria a "loucura diferente" nos termos de Lispector:

A obra de arte é um ato de loucura do criador. Só que germina como não-loucura e abre caminho. É, no entanto, inútil planejar essa loucura para chegar à visão de mundo. A pré-visão desperta do sono lento da maioria dos que dormem ou da confusão dos que adivinham que alguma coisa está acontecendo e vai acontecer. A loucura dos criadores é diferente da loucura dos que estão mentalmente doentes. Estes, entre outros motivos que desconheço, erraram no caminho da busca. São casos para médicos, enquanto os criadores se realizam com o próprio ato de loucura. (A descoberta do mundo 305)

A cronista, em sua sã lucidez, percebe a existência de duas loucuras: a da criação e a da doença. Segundo os operadores de leitura utilizados aqui, falaríamos em desrazão, no caso dos artistas, e loucura como doença mental no segundo caso. A "visão de mundo" (novamente a menção à potência do olhar), que seria fruto da loucura criadora, advém de uma pré-visão nascida do sono e "da confusão dos que adivinham," ou seja, de um lugar distinto da vigília, cuja proximidade com o inconsciente parece inequívoca. Adivinhos e sonhadores são avizinhados à desrazão da arte. Voltamos aqui à Platão, que associava o delírio ou mania (loucura) à arte divinatória (maniké). Tal aproximação faz do delirante um sábio. 
Diz Platão no Fedro: "O delírio [...] é uma coisa mais bela que o bom senso" (citado em Pelbart, Da clausura 80). Os rituais seriam mediações para a aparição do delírio, cuja expressão oracular caracterizava-se por ser sempre ambígua e obscura, alusiva e oblíqua. ${ }^{2}$

A cronista moderna sabe que pelo mesmo caminho de um saber desarrazoado, mas que se realiza na forma artística, muitos podem se perder. A fonte é a mesma e os motivos que definem os rumos da encruzilhada são impenetráveis ("por motivos que desconheço," diz a narradora). O trânsito da loucura para o que germina como não loucura na arte supõe um processo que implica libertação e não enclausuramento. A crônica revela a grande transformação histórica do estatuto da desrazão ao ser dominada pelos procedimentos da medicalização no século XVIII (os loucos passariam a ser "casos para médicos," diz o texto), indicando que a versão clínica da loucura é hoje o que chamamos de doença mental. Fato é que a "loucura" do artista (as aspas chamam atenção para mudanças históricas desse termo) recuperaria algo da dimensão de uma "verdade do mundo," em contraposição à loucura/doença em que se enuncia, de forma rebaixada, a "verdade do homem," como vimos acima. Foucault nomeia esse segundo tipo de loucura como "loucura-crítica," na esteira dos filósofos que a viram da perspectiva da baixeza moral do homem, como Brant, Erasmo e Montaigne (29).

\section{Arte, medo e liberdade}

A intuição clariciana, exposta nas crônicas examinadas, vai ainda mais longe em outra crônica publicada em 31 de maio de 1969 no Jornal do Brasil. Trata-se do texto "Medo da libertação," que dialoga com o anterior em mais de um sentido, ampliando significações já abordadas. Partindo de um quadro de Paul Klee, Lispector problematiza a arte, o medo, a liberdade e o hábito:

Se eu me demorar demais olhando Paysage aux oiseaux jaunes (Paisagem com pássaros amarelos, de Klee), nunca mais poderei

\footnotetext{
2 Segundo Heráclito: "O mestre cujo oráculo está em Delfos não afirma nem oculta, mas dá signo" (113). A mesma frase traduzida por Haroldo de Campos marca a ambiguidade do discurso divinatório: "O Oráculo/ em Delfos/não fala/nem cala/assigna" (citado em Pelbart, Da clausura 27).
} 
voltar atrás. Coragem e covardia são um jogo que se joga a cada instante. Assusta a visão talvez irremediável e que talvez seja a da liberdade. O hábito que temos de olhar através das grades da prisão, o conforto que traz segurar com as duas mãos as barras frias de ferro. A covardia nos mata. Pois há aqueles para os quais a prisão é a segurança, as barras um apoio para as mãos. Então reconheço que conheço poucos homens livres. Olho de novo a paisagem e de novo reconheço que covardia e liberdade estiveram em jogo. A burguesia total cai ao se olhar Paysage aux oiseaux jaunes. Minha coragem inteiramente possível me amedronta. Começo até a pensar que entre os loucos há os que não são loucos. E que a possibilidade, a que é verdadeiramente, não é para ser explicada a um burguês quadrado. E à medida que a pessoa quiser explicar se enreda em palavras, poderá perder a coragem, estará perdendo a liberdade. Les oiseaux jaunes não pede sequer que se o entenda: esse grau é ainda mais liberdade: não ter medo de não ser compreendido. Olhando a extrema beleza dos pássaros amarelos calculo o que seria se eu perdesse o medo. O conforto da prisão burguesa tantas vezes me bate no rosto. E, antes de aprender a ser livre, tudo eu aguentava — só para não ser livre. (A descoberta do mundo 198$)^{3}$

O texto é contundente, sendo difícil não reconhecer, ainda que de modo velado, o pano de fundo da política brasileira à época. Em plena ditadura militar, o jogo entre covardia e coragem, medo e liberdade, mencionado nas primeiras linhas, dominava a população, sob um regime de violência, terror e submissão. A proposição da cronista pode ser lida em chave paralela: ao lado do medo objetivo da prisão que ameaçava intelectuais de esquerda, estudantes e militantes de oposição, a autora desloca o assunto e focaliza o nosso medo de ser livre através da arte. O elemento subversivo, que não seria entendido pelo "burguês quadrado," é a própria arte e sua capacidade de nos tirar do hábito, de causar

\footnotetext{
${ }^{3}$ Esse mesmo texto foi originalmente publicado em A Legião estrangeira, com o título "Paul Klee." Reaparece como crônica no Jornal do Brasil em 1969. No caso desta crônica, tomamos esta última versão como base, uma vez que recebeu várias alterações importantes, respondendo ao seu tempo, como veremos, de forma ainda mais incisiva.
} 
estranhamento. "A burguesia total cai ao se olhar Paysage aux oiseaux jaunes," afirma a escritora. Contrapondo a prisão concreta e exterior para onde eram levados os ditos transgressores da ordem após o golpe de 1964 (e sobretudo a partir da proclamação do Ato Institucional número 5, o AI5, em 13 de dezembro de 1968, no governo do então presidente Costa e Silva), a cronista trabalha uma outra modalidade de aprisionamento subjetivo, que seria a habituação e a acomodação ("o conforto da prisão burguesa"), frutos do medo da liberdade. No texto de 1964, não aparece em nenhum momento a palavra "burguês." Já na versão posterior de "Medo da libertação," a autora parece querer explicitar sua percepção do embate sócio-político do período.

O quadro de Klee, de 1923, não é propriamente descrito pelo texto cronístico, mas sim recriado pelo ponto de vista da escritora, que se vê olhando a pintura (um olho que se olha no ato de ver) e expressando as ressonâncias desse olhar em si mesma. O início relembra o primeiro parágrafo do conto "Os obedientes," já citado, no qual a parada implicava perigoso afundamento. No caso de "Medo da libertação," é o olhar demorado sobre a obra de arte que corre risco de perdição, afirmando o poder transformador da arte: "Se eu me demorar demais olhando Paysage aux oiseaux jaunes . . . nunca mais poderei voltar atrás." Também o enunciador pode "afundar dentro" se parar um instante a mais diante do objeto, no caso, uma obra de um artista de vanguarda suíço. Aproveito aqui a observação de Herbert Read sobre Klee: "Like Chagall [Klee] has created his own world - a world with its own strange flora and fauna, its own laws of perspective and logic" (167). Nada mais íntimo ao universo de Lispector, que também transtorna os princípios lógicos convencionais e provoca o estranhamento como atitude de desfamiliarização, no sentido que essa palavra adquire para Viktor Chklovsky:

E eis que para devolver a sensação de vida, para sentir os objetos, para provar que pedra é pedra, existe o que se chama arte. $\mathrm{O}$ objetivo da arte é dar a sensação do objeto como visão e não como reconhecimento; o procedimento da arte é o procedimento da singularização dos objetos e o procedimento que consiste em obscurecer a forma, aumentar a dificuldade e a duração da percepção; o ato de percepção em arte é um fim em si mesmo e 
deve ser prolongado. A arte é um meio de experimentar o devir do objeto; o que é já 'passado’ não importa para a arte. (45)

Chklosvky afirma que em arte "a liberação do objeto do automatismo perceptivo se estabelece por diferentes meios" (45). No caso de Lispector, as transgressões sintáticas do texto em exame-como definições que não definem, frases inconclusas e pontuação pouco habitual—dão à crônica uma modernidade compartilhada pelo artista plástico que ela traz à tona. Sobre isso, diz Joelma Santana Siqueira: "A linguagem dramatiza em sua materialidade o sentido que encerra, permitindo-nos propor que a coragem relaciona-se com a ousadia para criar formas livremente, e a covardia com a obediência às normas, à tradição" (209).

Chamo atenção do leitor para a atmosfera aquática que envolve o quadro de Klee, subvertendo a esfera aérea em que os pássaros, em princípio, estariam alocados. Curiosamente, tal subversão pode habitar a arte, enquanto a autora se confessa assustada com a liberdade que ela vislumbra através das grades de sua prisão pessoal, limitada, mas segura e confortável. "Minha coragem, inteiramente possível, me amedronta," afirma. Ao olhar a pintura, a cronista também se observa em suas reações de medo, coragem e covardia. A primeira pessoa do singular, na abertura do texto, alterna com a primeira do plural, envolvendo os leitores e instaurando a cumplicidade na leitura. Somos nós também leitores habituados, estranhando uma escritora disruptora de limites, mas que se sente aprisionada, olhando por sua vez um artista radical e com ele aprendendo a liberdade maior. O jogo de espelhos, como na notável pintura de Diego Velázquez, As meninas (1655), cria deslocamentos que perturbam a visão apaziguada do leitor. Do mesmo modo, o quadro de Klee descentra a mirada ordenadora ao dispor seus elementos figurativos fora da perspectiva conhecida. Cito novamente Siqueira:

Diante desta imagem o que nos toca em primeiro lugar é a impossibilidade de definirmos apenas uma direção de ponto de vista. A imagem do pássaro de cabeça para baixo soa como um eco que diz: o que estamos vendo poderia ser visto de outro modo, pois quebra com a ideia de uma única possibilidade de direção para olharmos as imagens. Não é o único elemento a produzir essa 
sensação. Temos também sugestão de espelhamento e ilusão de simetria e profundidade. (213)

Importa compreender que Klee não é o tema da crônica, mas ponte para a discussão de assuntos diversos, entre eles a libertação através da arte. O engajamento da autora em um momento político extremo se dá pelo exercício da forma literária da crônica, convocando o leitor a se desabituar e expandir as "barras frias de ferro" de sua própria prisão cotidiana. A poética do risco de Lispector ronda seus textos, desconstruindo a razão hegemônica e propondo novos arranjos tão desarrazoados na linguagem textual quanto os de Klee na pintura.

\section{Loucura e verdade}

A contraposição entre artistas (não loucos, mas considerados por muitos como tais) e os loucos doentes aparece novamente na frase "Começo até a pensar que entre os loucos há os que não são loucos." É preciso comungar com um certo tipo de desrazão para adentrar o universo louco da arte e dele depreender suas verdades. A coincidência entre loucura e verdade aparece em mais crônicas, das quais destaco algumas frases de duas delas. A primeira, "Menino a bico de pena" (publicada no Jornal do Brasil em 18 de outubro de 1969), também trabalha na intersecção da palavra e da imagem, tentando desenhar um menino na sua atualidade. Mas o presente desse sujeito, que ainda está adquirindo a linguagem, é impossível de ser abarcado pelo simbólico, instrumento incapaz de capturá-lo e conhecê-lo. É preciso "esperar que ele [o menino] se deteriore": "um dia o domesticaremos em humano, e poderemos desenhá-lo" (A descoberta do mundo 241), diz o enunciador em primeira pessoa. Esse eu cronista, no entanto, não ocupa o centro do relato, como nas crônicas vistas até agora, embora seja um observador mobilizado diante de um outro - embate crucial e matriz de tantas narrativas da autora. O menino da crônica "coopera com sua domesticação," fazendo "o sacrifício de não ser louco. Eu não sou louco por solidariedade com 
os milhares de nós que, para construir o possível, também sacrificaram a verdade que seria uma loucura" (A descoberta do mundo 241), comenta a cronista. ${ }^{4}$

Dominar a loucura para tornar-se humano revela-se um topos da obra de Lispector que tem nas crônicas um lugar de representação ao mesmo tempo fragmentário e potente. O processo de socialização, na visão da autora, implica um sacrifício instintual que coincide com a perda da liberdade e - mais aindacom a perda da verdade. Portanto, ao aproximar a loucura da verdade, desde que aquela seja porta voz da desrazão e que a doença não a silencie, Lispector reencontra na verdade louca aquela linhagem dos poetas, profetas e desatinados do mundo que vimos no texto de Wisnik, comentado acima. Mas o preço dessa "perigosa lucidez" na sociedade dessacralizada e reificada é alto demais, podendo de fato levar à doença mental.

Antes de retomarmos a crônica "Medo da libertação," e ainda pensando a articulação entre loucura e verdade, há uma segunda crônica que toca de perto o mesmo tema. O texto "Mineirinho" também foi publicado na Parte II da primeira edição de A legião estrangeira, ressurgindo em 1978 no volume Para não esquecer. Ali, a revolta da autora se explicita e sua mirada para um marginal morto com treze tiros pela polícia no Rio de Janeiro, em 1962, adquire o formato de um libelo pela justiça social. Mas destaco apenas o que se relaciona com nosso foco. A voz da cronista, que se esconde na declinação masculina, acredita que só é possível conhecer a esse sujeito enlouquecido, condenado a mais de 100 anos no manicômio judiciário, se também formos doidos:

Feito doido, nós o conhecemos, a esse homem morto onde a grama de radium se incendiara. Mas só feito doidos, e não como sonsos, o conhecemos. É como doido que entro pela vida que tantas vezes não tem porta, e como doido compreendo o que é perigoso compreender, e só como doido é que sinto o amor profundo, aquele que se confirma quando vejo que o radium se irradiará de qualquer modo, se não for pela confiança, pela esperança e pelo amor então miseravelmente pela doente coragem de destruição. Se não fosse doido eu seria oitocentos policiais com oitocentas

\footnotetext{
${ }^{4}$ Também essa crônica é uma reescrita modificada do texto originalmente publicado em A legião estrangeira, com o título "Desenhando um menino."
} 
metralhadoras, e esta seria a minha honorabilidade. (A legião estrangeira 256)

Pode-se dizer que nesse trecho a autora convoca uma cumplicidade de todos com o terreno da desrazão, que implica reconhecer o inumano de que somos feitos (o radium), a irracionalidade e a destrutividade que explodem em Mineirinho na forma de um doente do crime. ${ }^{5} \mathrm{O}$ estado de ser doido (diferenciado do "sonso" ou alienado, termos mencionados em outros trechos do texto) permite a compaixão e uma compreensão do que "é perigoso compreender." Notemos como é recorrente nos textos já visitados a ideia de que existe um campo incompreendido pela percepção habitual e que apenas um determinado estado (desarrazoado?) fornece o acesso ao que permanece como silêncio. Tocar esse resto que se cala representa o perigo da escrita e da vida.

Após esse breve excurso, voltemos à crônica "Medo da libertação." A frase final ("E, antes de aprender a ser livre, tudo eu aguentava—só para não ser livre"), ${ }^{6}$ reforça a ideia das grades como proteção à desestruturante liberdade, a mesma que acompanha a "lucidez perigosa" e "a doce corrente" do devaneio. A contabilidade dessa economia psíquica leva a um desequilíbrio sintomático ("tudo eu aguentava") em nome de sustentar a posição aprisionada. Não é outra, afinal, a proposição psicanalítica quando teoriza os processos de constituição do sintoma neurótico. Entendido como formação de compromisso entre as demandas da pulsão e os caminhos possíveis da sua representação no intercâmbio social, o sintoma faz um "pacto" entre ambos para permitir uma satisfação, ainda que parcial. Tudo aguentar para não ser livre, como diz a cronista, implica, necessariamente, defender-se do desejo de liberdade por "medo da libertação." O conforto das grades é, paradoxalmente, a expressão do pacto.

Tomemos mais um texto jornalístico em forma de fragmento, agora em terceira pessoa onisciente e distante da matéria relatada, marcado aqui pela feição ficcional. Ele acena exatamente para a condição adaptativa enquanto percurso mortificante. É o caso do pequeno trecho "Não sentir," em A descoberta do mundo: "O hábito tem-lhe amortecido as quedas. Mas sentindo menos dor,

\footnotetext{
${ }^{5}$ Para uma leitura mais pormenorizada de "Mineirinho," ver Rosenbaum (“Ética na literatura”). ${ }^{6} \mathrm{Na}$ primeira versão de 1964, a frase se coloca no presente: "Tudo o que eu tenho aguentado—só para não ser livre".
} 
perdeu a vantagem da dor como aviso e sintoma. Hoje em dia vive incomparavelmente mais sereno, porém em grande perigo de vida: pode estar a um passo de estar morrendo, a um passo de já ter morrido, sem o beneficio de seu próprio aviso prévio" (32). Como abordar esse texto à luz de tudo o que já foi percorrido? O hábito adquire aqui o estatuto de um remédio mortífero, que aplaca a dor e apaga o sujeito. Com isso ele se sereniza, mas também se aproxima da morte. A ironia, que fala da vida pelo caminho da morte, rege o texto e com ela Lispector constrói um fragmento narrativo onde a personagem avança pela via mortífera quanto mais se normatiza pelo hábito. A normalidade é ela mesma o lugar do enlouquecimento: o sujeito do texto desenvolve um "sintoma normal," ou seja, vive para aplacar a dor e com isso perde a si mesmo.

A proximidade com o conto "Os obedientes," cujo primeiro parágrafo já conhecemos, é inequívoca. Também o casal do conto se esforça para habitar a normalidade como um padrão a seguir: " 'Ser um igual' fora o papel que thes coubera, e a tarefa a eles entregue" (A legião estrangeira 101). Ou ainda: "Eles nunca se lembrariam de desobedecer" (A legião estrangeira 115). Aplacavam a dor, mantendo-se como "pessoas anônimas," segundo o narrador, que se coloca entre a onisciência e o testemunho. Sem dúvida, aqui a desrazão, esse grande território do Desconhecido, sequer se coloca como horizonte de contato para o casal, já que "não era uma vida de sonho, pois este jamais os orientara." No entanto, havia momentos em que eles tocavam um fundo incognoscível e perigoso, "de onde ninguém pode passar" (A legião estrangeira 102).

\section{Trânsito interrompido}

Por fim, resta uma última mirada sobre um texto cujo núcleo é precisamente a loucura e a decorrente internação. A crônica "Das doçuras de Deus" (16 de dezembro de 1967) compõe, com mais três outros textos jornalísticos ("A mineira calada," de 8 de novembro de 1967, "Por trás da devoção," de 2 de dezembro de 1967 e "De outras doçuras de Deus," de 16 de dezembro de 1967), uma espécie de quarteto sobre uma mesma personagem, no caso a empregada doméstica Aninha, mineira e calada, que de fato trabalhou na casa de Lispector. Em "Das doçuras de Deus," a autora relata o dia em que Aninha voltou da rua diferente: "Havia uma coisa nova nela. O quê, não se adivinhava. Talvez uma doçura maior" (A descoberta do mundo 53). A empregada, de expressão "pueril 
e límpida," trazia no saco, que deveria ter as compras da venda, um monte de tampinhas de garrafas de leite e papéis sujos. Jandira, a cozinheira vidente (personagem da crônica "A vidente," de 25 de novembro de 1967) chamara a ambulância: "Fui ver. Estava calada, doida. E doçura maior nunca vi" (A descoberta do mundo 54). Notem que a vidência da cozinheira Jandira é que reconhece o estado endoidecido de Aninha, reafirmando a vizinhança entre ambas, a louca e a vidente.

Quando Aninha é levada para o pronto socorro psiquiátrico, a cronista assim descreve sua partida: "E lá se foi Aninha, suave, mansa, mineira, com seus novos dentes branquíssimos, brandamente desperta. Só um ponto nela dormia: aquele que, acordado, dá a dor" (A descoberta do mundo 54). Vários elementos se conjugam aqui. A mineira calada que, banguela, aceita colocar dentes por insistência da patroa (talvez para esconder a boca precária e pobre), é tratada pela autora com extrema delicadeza e respeito. Sua loucura é referida como silenciosa, mansa, doce. Ela é descrita como "brandamente desperta," caracterizando seu quadro a meio caminho entre o sono e a vigília, lugar que seria passagem da desrazão, mas que se torna ponto de fixação, estado congelado da loucura. Como doida, é possível para Aninha adormecer a dor. A loucura/doença apresenta-se aqui como forma de anestesia e não de despertar.

A presença ausente de Aninha mobiliza a autora, que passa a noite sentada na sala fumando, entregue à sua própria introspecção, quem sabe se também endoidecida: "A casa estava toda impregnada de uma doçura doida, como só a desparecida podia deixar" (A descoberta do mundo 54). De uma alteridade distante da cronista, como parecia ser inicialmente a empregada doida, caminhase para uma identificação entre ambas, conjugadas pelo ato da escrita e da loucura. O médico que primeiro examina Aninha pergunta o porquê das tampinhas e dos papéis sujos que trazia no saco, ao que ela responde que seriam para enfeitar o quarto. A esse respeito, vale citar aqui a passagem do belo ensaio de César Mota Teixeira sobre A Hora da estrela, com um notável excurso sobre as crônicas com empregas domésticas na obra de Lispector. No trecho em que comenta "Das doçuras de Deus," é visível, como aponta Teixeira, a inspiração da teoria do psiquismo de Melanie Klein:

Voltando um pouco, percebe-se que os 'restos' de objetos encontrados no saco de compras, imagem especular do 'de dentro' 
da personagem, seriam usados numa atividade construtiva e estética, simbolicamente reparatória do sentimento esquizóide de destruição interior vivido pelo eu. Sugere-se que a loucura se aproxima da escrita pelo seu lado produtivo de construir sobre ruínas, de dar forma ao caos, de procurar expressão para os sentimentos 'vagos e sufocadores' (afinal Aninha estava suave, mansa, doida, doce), de inventar enfim uma lógica outra. Não será preciso lembrar que a arte de Clarice se aproxima de todas estas atitudes sugeridas pela loucura de Aninha, principalmente quando pensamos que 'papéis sujos' podem ser os objetos comuns da atividade estética de ambas: dos enfeites para o quarto de uma e da escrita da outra (aliás, é sobre papel que se escreve!). (62)

O modo de aproximação entre as personagens se dá justamente pela ponte da desrazão, mas onde Lispector cria sua obra, Aninha sucumbe. Por um momento, a atmosfera da casa, "impregnada de uma doçura doida," propicia que a escritora se irmane com o seu outro de classe, anulando a disparidade social que constitui a relação entre patroa e empregada. Da distância ao encontro, da diferença à identidade, da incompreensão à afinidade. Esse parece ser o movimento de muitos embates entre narradores e personagens claricianos ou desses entre si ao longo da obra da autora. ${ }^{7}$

Mas é na frase final que é preciso se deter e reunir os fios lançados neste ensaio: "Aninha, meu bem, tenho saudade de você, de seu modo gauche de andar. Vou escrever para sua mãe em Minas para ela vir buscar você. O que the acontecerá, não sei. Sei que você continuará doce e doida para o resto da vida, com intervalos de lucidez" (A descoberta do mundo 55). O "modo gauche de andar" da personagem não deixa de remeter a um outro mineiro famoso, o poeta Carlos Drummond de Andrade em seu "Poema de sete faces." Poetas e loucos se afinam em seu desatino, ainda que se diferenciem na encruzilhada. Enquanto a lucidez perigosa, limiar da loucura, é o lugar do visionarismo poético e permite

\footnotetext{
${ }^{7}$ Ver também Pontieri; Kahn; e Gotlib. Como exemplo desse jogo de distância e espelhamentos, citemos G.H. e a barata em A paixão segundo G.H., e o narrador Rodrigo e Macabéa, em A hora da estrela. O que se inicia como radical aversão entre as duplas de personagens transita, não sem conflito e resistência, para uma consciência de imprevistas - e muitas vezes indesejáveissemelhanças. No caso específico da crônica, é no espelho da loucura de Aninha que Lispector reconhece algo de sua desatinada escrita.
} 
o trânsito pela desrazão, a loucura "doce e doida" de Aninha impede o fluxo da vida psíquica e afasta o sujeito da realidade, sem saída para o mundo exterior.

Chama atenção a mudança da crônica para o registro epistolar como modo de aproximação e intimidade entre empregada pobre e a patroa de outra classe social. A escritora se deixa tocar pela loucura de Aninha, mas invertendo os termos da equação: enquanto, por um lado, a doida empregada tem "intervalos de lucidez" (e aqui "lucidez" não seria tanto aquela "lucidez vazia" da crônica de abertura deste ensaio, mas apontaria no sentido da normalidade compartilhada), no trajeto inverso está a cronista/ artista, tomada por momentos desatinados em meio ao cotidiano habitual. Aninha, afinal, é seu duplo invertido. No último texto dedicado à Aninha, "De outras doçuras de Deus," ela ainda não tem alta psiquiátrica definitiva - depois de engordar com soros e submeter-se a três choques elétricos - mas já está melhor e visita a patroa para buscar seu dinheiro (parâmetro de retorno ao mundo das trocas racionais). "No hospital," relata a cronista, "descobriram as potências de Aninha, e, depois que tiver alta, vai ficar lá trabalhando por uns tempos. Nossa casa estava alegre" (A descoberta do mundo 55). O final reparador traz um alento ao leitor e à escritora. A descoberta no hospital das "potências de Aninha" mostra afinidades com as potências criativas da arte, território da desrazão. Reparação, reconstrução e criatividade parecem enlaçar artista e doida, em uma inusitada comunhão. ${ }^{8}$

\section{Pontos de chegada}

Como religar os fios lançados até aqui? A complexidade da escritora se fez notar nas múltiplas faces da loucura e da desrazão desentranhadas de suas crônicas no Jornal do Brasil. Ainda que não se tenham convertido em contos ou romances, nem deles retiradas para publicação no jornal, as crônicas acima comentadas parecem constituir uma matriz temático-formal do que reconhecemos como marcas da autora. As reversibilidades entre louco e não louco, os conflitos entre cultura e pulsão, a força do hábito, o embate entre a normatização e o

\footnotetext{
${ }^{8}$ Vale notar que na crônica "Por trás da devoção" (2 de dezembro de 1967), Aninha é mencionada apenas no início, cedendo espaço à outra empregada, Maria del Carmen. A menção à "mineira calada", alcunha que dá título à primeira crônica sobre Aninha, enfatiza sua "voz abafada" e conta como a patroa cismava em chamá-la de "Aparecida". Aninha explica: "É porque eu apareci" (A descoberta do mundo 49).
} 
desregramento, afinidades e desencontros entre arte e loucura, estranhamentos e identificação entre alteridades, as fronteiras entre loucura e desrazão.

Enfim, a crônica, tão familiarmente considerada como o gênero da contingência leve e fortuita, adquire na obra de Lispector uma densidade inusitada. Nela, o perigoso jogo entre lucidez e desvario lança sementes explosivas que se propagam por toda obra, atingindo o leitor de formas renovadas a cada novo texto.

\section{Obras citadas}

Blanchot, Maurice. L'entretien infini. Gallimard, 1969.

Chklovski, Viktor. "A arte como procedimento." Teoria da literatura: formalistas russos. Globo, 1976, pp. 39-56.

Deleuze, Gilles. Crítica e clínica. Traduzido por Peter Pál Pelbart. Editora 34, 1997.

Foucault, Michel. História da loucura na idade clássica. Perspectiva, 1978.

Freud, Sigmund. "O mal estar na civilização.” Obras completas, Imago, 1974, pp. 81-171.

—. "Formulações sobre os dois princípios do funcionamento mental." Obras completas, Imago, 1969, pp. 277-86.

Gotlib, Nádia B. Uma vida que se conta. U de São Paulo, 2009.

Kahn, Daniela M. A via crucis do outro: identidade e alteridade em Clarice Lispector. Humanitas/ Fundação de Amparo à Pesquisa do Estado de São Paulo, 2005.

Levy, Tatiana Salem. A experiência do Fora: Blanchot, Foucault e Deleuze. Civilização Brasileira, 2011.

Lispector, Clarice. A descoberta do mundo. Rocco, 1999.

—. A hora da estrela. Rocco, 1977.

- A legião estrangeira. Edição do Autor, 1964.

-. A paixão segundo G.H. Rocco, 1964.

—. Laços de família. Francisco Alves, 1991.

—. Para não esquecer. Ática, 1978.

—. Perto do coração selvagem. José Olympio, 1977.

Nunes, Benedito. O drama da linguagem. Ática, 1989. 
Pelbart, Peter P. “Da loucura à desrazão.” A nau do tempo rei, Imago, 1993, pp. 91-99.

- Da clausura do fora ao fora da clausura. Iluminuras, 2009.

Pellegrino, Hélio. Lucidez embriagada. Editado por Antonia Pellegrino, Planeta, 2004.

Pena, João Camillo. "O nu de Clarice Lispector." Alea, vol. 12, no. 1, 2010, pp. 68-96.

Pontieri, Regina. "Os tantos outros que sou." Revista Cultura Vozes, edição 4, 1994, pp. 26-30.

Read, Herbert. The Meaning of Art. Faber, 1950.

Sá, Olga de. A escritura de Clarice Lispector. Vozes, 1993.

Sant'Anna, Affonso Romano de. Análise estrutural do romance brasileiro. Vozes, 1979.

—. "Clarice: a epifania da escrita." A legião estrangeira. Ática, 1985, pp. 3-7.

Siqueira, Joelma S. "Interartes na escrita de Clarice Lispector." Cadernos de Letras da UFF, no. 44, 2012, pp. 207-18.

Rosenbaum, Yudith. "Ética na literatura: leitura de 'Mineirinho,' de Clarice Lispector" Revista de Estudos Avançados, vol. 24, no. 69, 2010.

-. Metamorfoses do mal: uma leitura de Clarice Lispector. U de São Paulo, 2006.

Teixeira, César M. Narração, dialogismo e carnavalização: uma leitura de A hora da estrela, de Clarice Lispector. 2006. U de São Paulo, Tese de doutoramento, teses.usp.br/teses/disponiveis/8/8149/tde-05102007145251/publico/TESE_CESAR_MOTA_TEIXEIRA.pdf

Wisnik, José M. "Diagramas para uma trilogia de Clarice”. Revista Letras, no. 98, 2018, pp. 282-307.

—. "Iluminações profanas (poetas, profetas e drogados)." O olhar, editado por Adauto Novaes, Companhia das Letras, 1988, pp. 283-99. 